\title{
Uncertain start in Montreal
}

\section{Montreal}

THE Fifth International Conference on AIDS got off to an uncertain start this week after AIDS activists stormed the entrance to the conference centre and held up the opening ceremony for almost an hour. Conference officials stood by nervously conferring on walkie-talkies as predominantly US activists chanted slogans and read a ten-point manifesto. The activists then seized the 50 or so seats reserved for conference VIPs, shouting "We are the VIPs". Only after other space was found did some of the activists relinquish their seats, and allow the programme - which juxtaposed Canadian prime minister Brian Mulroney, Zambian president Kenneth Kaunda, and a videotape of the recently deceased founder of the Vancouver Persons With AIDS Societyto begin.

This year's conference, with a record 10,789 participants registered on the opening day, is quite different from its predecessors. The clinical, basic research and epidemiology sections are still the largest, but perhaps reflecting the failure so far to find a cure or effective vaccine, the other six sections concentrate on the effects of the AIDS pandemic on society. Sessions on the economic impact of AIDS, ethical and legal issues, and international cultural differences are interleaved with those on "AIDS and the Individual" and "AIDS, Society and Behaviour". The organizing committee, chaired by Ivan Head of the Canadian International Development Research Centre, has a distinctly liberal bent, and includes for the first time a person with AIDS.

Head made a point in his address to acknowledge the AIDS activists in the audience: "As with all good parties, more people attend than you are prepared for", he said, adding "I am delighted you are all here". The opening remarks included no hints that significant developments in the understanding or treatment of AIDS were to come later in the week, but painted a grim picture of the challenge AIDS presents to society. Jonathan Mann, director of the World Health Organization AIDS programme, said the estimated halfmillion worldwide AIDS cases represent three epidemics: viral infection, disease and society's "extraordinarily complex and increasingly diverse" response. Mann predicted the present number of AIDS cases will double to more than 1.1 million by the end of 1991, but that over one-third can be prevented through educational campaigns, in which community-based organizations play an integral part. To loud applause, Mann issued a final challenge: " ...is the world now mature enough, now wise enough to accept that the deepest meaning of solidarity requires that we consider ourselves as if we too were infected with HIV?"

President Kaunda offered a very personal note in his keynote speech, when he recounted the death of his oldest son from
AIDS more than two years ago. Kaunda emphasized that the AIDS epidemic "adds a new dimension to the destruction of the human body", particularly in Africa, where malnutrition, malaria and other infectious diseases already drastically shorten life.

In response to the question of a possible African origin for the AIDS virus, Kaunda said the seriousness of the pandemic overshadowed speculation that the virus evolved "in the tail of a monkey" or "jumped out of a test-tube of a hardnosed researcher". Kaunda likened the AIDS epidemic to a "soft, silent nuclear bomb" that "laugh[s] at mankind and our wicked plans for self-destruction". He called for diverting the money being spent on nuclear weapons into AIDS research, saying "AIDS can do that killing for man worldwide at no cost in dollars and roubles."

Carol Ezzell

\section{UK UNIVERSITIES}

\section{End to exam boycott}

\section{London}

BRITISH university lecturers have narrowly voted to accept the pay settlement agreed last month between the university management and the lecturers' union, bringing to an end the five-month boycott of examinations which had threatened to delay the awarding of degrees to final-year students.

On a turnout of 68 per cent of the 30,000 member union, 55 per cent voted in favour and 45 per cent against the settlement, which gives lecturers a rise of 6 per cent from 1 April and a lump sum of between $£ 150$ and $£ 285$ depending on what each university can afford.

The lecturers' action began in January with a refusal to cooperate in any examination procedures, which was later scaled down to a refusal to mark papers. Apologizing for offering a pay rise of only 3 per cent, the Committee of Vice-Chancellors and Principals (CVCP) insisted that universities could afford no more. After the CVCP persuaded the government to release additional funds, the offer was increased to a pay rise of 6 per cent, backdated to April 1989, plus an extra 1 per cent to be distributed at the discretion of individual universities and a lump sum of between $£ 150$ and $£ 285$. The lecturers refused this offer.

The argument of the CVCP throughout the dispute has been that although it recognize that the offer was too low, universities simply could not afford any more. Instead of accepting the offer and claiming victory at that point, the union was determined to continue, arguing that still no money had been offered for 1988-89. Accepting an offer worth only about $£ 50$ more three months later reflects acknowledgement of members that the cost to students of prolonging the dispute would be too great.

Christine McGourty accident." He was, he points out, serving on SIPI's board well before he was caught their information" through television. Seth Shulman 